\title{
ПЕДАГОГІЧНІ УМОВИ ОРГАНІЗАЦІЇ ДИСТАНЦІЙНОГО НАВЧАННЯ В УНІВЕРСИТЕТІ
}

\begin{abstract}
Анотація. У статті розглянуто особливості «дистанційного навчання» як педагогічної технології та визначено основні теоретико-прикладні аспекти її реалізації в умовах закладу вищої освіти. Описано проблеми системи організації дистанційного навчання у закладах вищої освіти. Проаналізовано дефініцію «освітне середовище» університету та встановлено його інституційний та функціональний зв'язок із поняттям «дистанційного навчання». Визначено та обгрунтовано забезпечуючі педагогічні умови організації дистанційного навчання в умовах освітнього середовища університету: організація дистанційного навчання в університеті повинна здійснюватися на засадах студентоцентрованого та компетентнісного підходів; умовою організащії дистанщійного навчання в освітньому середовищі університету є особистісний та професійний розвиток студента; трансформація організаційно-змістового та предметно-фрункціонального компоненту освітнього середовища ЗВО до вимог цифровізації дистанційного навчання; готовність студентів до навчання в освітньому середовищі університету із впровадженням дистанційної технології.
\end{abstract}

Ключові слова: освітне середовище, дистанційне навчання, дистанційна освіта, педагогічні умови, освітні онлайн-платформи.

Yaremchuk Nataliya, Marusova Valeria Ivan Franko National University of Lviv

\section{PEDAGOGICAL CONDITIONS OF ORGANIZATION OF DISTANCE LEARNING AT THE UNIVERSITY}

Summary. Abstract. The article considers the features of "distance learning" as a pedagogical technology and identifies the main theoretical and applied aspects of its implementation in a higher education institution. The problems of the system of organization of distance learning in higher education institutions are described. The definition of "educational environment" of the university is analyzed and its institutional and functional connection with the concept of "distance learning" is established. The providing pedagogical conditions for the organization of distance learning in the educational environment of the university are defined and substantiated: the organization of distance learning at the university should be carried out on the basis of student-centered and competence-based approaches; the condition of the organization of distance learning in the educational environment of the university is the personal and professional development of the student; transformation of the organizational-content and subject-functional component of the educational environment of the Free Economic Zone to the requirements of digitalization of distance learning; readiness of students to study in the educational environment of the university with the introduction of distance technology. The main problems of the organization of distance learning in higher education institutions are highlighted: the lack of clear legal provisions and guidelines; lack of free software and software; the cost of time for the implementation of pedagogical activities of teachers; lack of a single educational platform for distance learning; the need for organizational, psychological, educational and methodological support of the administration of the Free Economic Zone participants in the educational process. The structural components, criteria and indicators of students' readiness for distance learning in the educational environment of the university are determined. The levels of readiness of students for distance learning are described: low, medium and high (creative).

Keywords: educational environment, distance learning, distance education, pedagogical conditions, online educational platforms.

$\Pi$ остановка проблеми. Актуальність дослідження зумовлена глобалізацією, що є однією 3 головних особливостей сучасного світу і стае каталізатором редормування традиційної системи освіти. Необхідність фрормування професійних компетентностей сучасних випускників університетів, що відповідають стрімкому розвитку техніки та технологій в усьому світі, вимагає пошуку нових підходів, інноваційних форм, методів і технологій навчання.

Діяльність сучасних освітніх установ реорганізуеться відповідно до розвитку та використання інформаційних технологій у поширенні знань, а це є одним із головних завдань покращення якості освіти у XXI столітті. Дистанційна освіта набувае більшої популярності в Україні через вплив західних тенденщій щодо розвитку безперервної освіти, економічної кризи та панде- мї COVID-19, коли традиційне навчання просто неможливе через карантинні обмеження.

Трансформуючі зміни у суспільному просторі, завдяки процесам гаджетилізації, віртуалізацї, штучного інтелекту та технічним можливостям, уможливили їх впровадження в освітній процес. Створення нової системи інфрормаційного простору освіти та середовища університету сформувало появу новітніх педагогічних технологій, зокрема, дистанційного (електронного) навчання.

Аналіз останніх джерел i публікацій. Тема дослідження дистанційного навчання присутня у наукових працях багатьох дослідників: концептуальні педагогічні положення дистанційного навчання (О. Андреєва, Г. Козлакова, В. Олійник, С. Полата, П. Стеданенко); педагогічні підходи до комп'ютеризації навчального процесу (Б. Гершунський, Є. Машбиць, I. Під- 
ласий); інформащійні, віртуальні та цифрові технології в освітньому процесі (В. Биков Р. Гуревич, М. Кадемія, Д. Опеншоу, Н. Тверезовська, I. Хорев, М. Жалдак, Ю. Жук); теоретико-методологічні основи дистанційної форми навчання (M. Бухаркіною, С. Гончаренком, В. Биковим, М. Моісеєвою, Є. Мушкою, Є. Полат); дидактичні основи дистанційного навчання (О. Андреєва, В. Кухаренко); психологічні аспекти системи дистанційного навчання (М. Жалдак, Ю. Ільїна, Ю. Машбіц, М. Назар); організаційно-педагогічні основи дистанційного навчання в умовах вищої освіти (В. Гравіта, Н. Клокар, Л. Ляхоцька, В. Олійник, В. Осадчий, С. Сисоєва, П. Таланчук, Н. Яремчук). Закордонна практика наукових досліджень теоретико-прикладних особливостей дистанційного навчання відображена у працях G. Dudeney, N. Hockly, P. Fidalgo, J. Thormann, A. Taurisson та ін.

Виділення невирішених раніше частин загальної проблеми. Проблема дистанщійного навчання представлена у низці багатоаспектних теоретико-методологічних наукових розвідок та практично-методичних засад, які представлені нормативно-правовим регулюванням та прикладним інструментаріем, проте педагогічні умови організації дистанційного навчання в освітньому середовищі університету як окреме авторське дослідження відсутне.

Формулювання цілей статті. Метою статті $є$ визначення та обгрунтування педагогічних умов успішної організації дистанційного навчання в освітньому середовищі університету.

Виклад основного матеріалу дослідження. Впровадження дистанційного навчання, на кожному етапі його розвитку, стало вагомою альтернативою в організації освітнього процесу у формальній та неформальній освіті. За певних обставин, дана інновація зробила конкурентний виклик аудиторному навчанню, проте відкрила низку організаційно-методичних суперечностей, вирішення яких задовільнить запит на якісну освітню послугу її споживачів. Показником можливості щодо повноцінного впровадження дистанційного навчання в освітній процес освітніх закладів стали карантинні обмеження, спричинені пандемією COVID-19. В цих умовах заклади освіти зустрілись із багатоаспектними проблемами щодо роботи у дистанщійному режимі, незважаючи на те, що проблема застосування інформащійних технологій в освітній інфраструктурі не була новою [10].

Н. Стеценко у своєму дослідженні виокремлюе головні проблеми організацї дистанційного навчання у закладах вищої освіти:

- наявність чітких нормативно-правових положень та методичних рекомендащій (MOH, ЗВО тощо). Оскільки процес організації дистанційного навчання $є$ відносно новим явищем, інструктивна база є критично необхідною для ефективного функціонування дистанційного освітнього процесу;

- забезпеченість ЗВО технічно-програмним забезпеченням, яке адаптоване до вимог здобуття вищої освіти (сайти, освітні платорорми, соціальні мережі, засоби комунікащії тощо). Відповідна інфраструктура постійно змінна у відповідності із прогресом процесів інфрорматизації та цифрровізації, проте залучення до освітнього процесу найбільш сучасних і відповідних $є$ вимогою для якісного дистанційного навчання;

- оптимальне фрункціонування мережі інтернет. Мережа інтернет є ключовим елементом дистанційного навчання, але його якість не завжди дозволяе якісно проводити заняття на відстані;

- затратність часу для здійснення педагогічної діяльності викладачів. Підготовка до онлайн заняття вимагае від викладача набагато більших зусиль, оскільки вимагає: спроектувати та впровадити дистанційний навчальний курс, обрати освітню платформу для подання навчально-методичного матеріалу, а також організувати онлайн заняття так, щоб всі учасники навчального процесу були активними, мотивованими та інтерактивними;

- проблема якісного україномовного відеоконтенту, який необхідний як структурний компонент дистанційного навчального курсу;

- відсутність єдиної освітньої платформи організації дистанційного навчання. Оскільки викладачі використовують різні платформи для навчання, що мають різний інтерфейс, студенти не завжди орієнтуються в тому, як саме відбуваеться організація процесу навчання;

- потреба організаційної, психологічної, навчально-методичної підтримки адміністрації ЗВО учасників освітнього процесу. Важлива побудова оптимальної педагогічної системи в ЗВО, яка б в умовах дистанційного навчання не формувала дискомфорту в організації учіння із сторони студента та можливість побудови педагогічної взаємодії із сторони викладача.

Виокремлення низки інституційно-управлінських та навчально-методичних суперечностей формуе необхідність багатоаспектного дослідження педагогічних умов організації дистанційного навчання в освітньому середовищі ЗВО. Відповідно важливий аналіз базових дефініцій, зокрема "освітнього середовища" та "педагогічних умов", також інтегрування їх у структурнофрунціональну єдність із технологією дистанційного навчання та розкриває потенціал для профресійного розвитку особистості майбутнього фрахівця

Дослідження особливостей «освітнього середовища» в умовах 3ВО грунтовно презентуе М. Братко. Науковиця, аналізуючи науково-педагогічні розвідки, засвідчує, що проблема вивчення впливу освітнього середовища на розвиток особистості актуалізувалась ще із 70-90 років XX століття, проте відповідно до сучасних методологічних аспектів має свої інноваційні погляди. Вивчення освітнього середовища варто аналізувати через аспекти: сощіально-психологічний (освітнє середовище визначається як умова конструювання людиною смислів у процесі взаємодії з оточуючим світом); соціально-педагогічний (освітне середовище визначається як багатомірне соціально педагогічне явище, яке ситуативно впливає на розвиток ціннисних орієнтацій, способів поведінки) [1].

В. Ясвін визначає «освітне середовище» як систему впливів та умов формування особистості за відповідним взірцем, а також можливостей для iii розвитку, які містяться в соціальному та просторово-предметному середовищі [1]. 
В. Панов під «освітнім середовищем» розуміе систему педагогічних i психологічних умов і впливів, які створюють можливості як для розкриття інтересів і здібностей, які ще не проявились, так і для розвитку здібностей, які потребують розвитку, а також розширення потенціалу особистостей студентів у відповідності до вікової періодизації та процесу соціалізації. Ця система включає діяльнісний (технологічний), комунікативний і просторово-предметний компоненти [1].

За Ю. Кулюткіним та С. Тарасовим, «освітне середовище» - це сукупність соціальних, культурних, а також спеціально організованих в освітньому закладі психолого-педагогічних умов, в результаті взаємодії яких з індивідом відбувається становлення особистості [1].

Л. Редько детермінуе «освітне середовище ЗВО», як «сукупність можливостей задоволення професійно-освітніх потреб студента для становлення його профресійної компетентності» [1].

Отже, можемо зробити висновок, що освітне середовище $є$ невід'ємним елементом освітньої системи 3ВО, що безумовно впливае і на формування особистості студента на шляху його профресійного становлення, і на педагогічну діяльність викладача, та їхню педагогічну взаємодію в умовах дистанщійного навчання.

Оцінка особливостей дистанційного навчання в умовах освітнього середовища 3ВО визначає широкий ресурс можливостей, проте вимагає проектування відповідних педагогічних умов, дотримання яких оптимізуе освітній результат.

Аналіз поняття «педагогічна умова» дозволяе його трактувати 3 позищії обставин, від яких залежить цілісний продуктивний педагогічний процес професійної підготовки фрахівців, що опосередковуеться активністю особистості, групою людей [3] або "стійкі обставини, які визначають стан i розвиток фрункціонуючих педагогічних систем» [3, с. 28]. Отже, виокремлення педагогічних умов співмірно із чинниками, обставинами, впливами, які безпосередньо чи опосередковано впливають на результат педагогічної системи ЗВО.

Відповідно до особливостей дистанщійного навчання виокремлюемо педагогічні умови його організації в освітньому середовищі ЗВО:

1) організація дистанційного навчання в університеті відбувається на засадах студентоцентрованого та компетентнісного підходів;

2) в умовах дистанційного навчання здійснюеться особистісний та професійний розвиток студента;

3) організаційно-змістовий та предметнофункціональний компоненти освітнього середовища ЗВО співмірні із особливостями цифровізації дистанційного навчання;

4) готовність студентів до дистанщійного навчання в освітньому середовищі університету.

Розглянемо кожну з них окремо.

Педагогічна улова шодо організаиї дистаниійного навчання в університеті на засадах студентоцентрованого та колпетентнісного підходів. Відповідно до методології особистісно зорієнтованого навчання, освітне середовища ЗВО повинно фрункціонувати на засадах студентоцентрованого підходу, що забезпечуе всебічний та гармонійний розвиток особистості студента, його самоідентифрікацію та самореалізацію, шляхом створення індивідуальної освітньої траєкторії.
Організація студентоцентрованого навчання є багатоаспектним феноменом, комплексна характеристика якого має врахувати низку обставин:

1) активна реакція освітянського середовища на мінливі потреби ринку праці;

2) модель розвитку освіти, за якої студент 3 об'єкта перетворюеться на суб'єкт освітньої діяльності, тобто на активного учасника науковоосвітнього процесу;

3) концентрація зусиль на передбаченні у плануванні педагогічного процесу індивідуальних якостей та здібностей студентів та формуванні індивідуальних освітніх траєкторій, відповідно, індивідуального профрілю компетенщій;

4) новий рівень відповідальності за створення умов, за яких на виході високі результати навчання та найсучасніші компетентності [9].

Організація дистанційного навчання на засадах студентоцентрованого підходу передбачає широкий спектр можливостей у виборі освітнього контенту в межах середовища ЗВО та освітнього глобального простору, які доповнюють зміст фрормальної освіти інформаційними освітніми ресурсами у формі вебінарів, майстер-класів, участю у форумах, дописами у блогах, чатах у соціальних мережах тощо.

Компетентнісний підхід, є ключовим в організації освітнього процесу в університетів, оскільки він визначає зміст та результат навчання. Усі компетентності (загальні і спеціальні), відповідно до спеціалізації, відображає освітня програма підготовки фрахівця. Їнне формування як особистісно-професійних якостей залежить від операційно-діяльнісного компоненту педагогічного процесу. В умовах дистанційного навчання це забезпечують відповідні методи і прийоми дистанційного навчання на онлайн-заняттях, організація самостійної роботи, науково-дослідницькі проекти тощо.

Отже, враховуючи базові методологічні підходи - студентоцентрований та компетентнісний, організація освітнього середовища, відповідно до особливостей дистанційного навчання, повністю відповідає встановленим освітнім стандартам.

Другою педагогічною уловою організацї̈ дистаниійного навчання в освітньому середовищі університету є особистісний та профбесійний розвиток студента. Методологічно обумовлено, що саме освітне середовище зумовлюе особистісне фрормування як забезпечуючий та координуючий чинник.

«Освітнє середовище - це загальний, сукупний, об'єднаний, інтегральний, цілісний чинник розвитку і становлення особистості, що відіграє значну роль у модифікації її поведінки, яка розгортається внаслідок запланованих і незапланованих впливів середовища, взаємодії особистості 3 його складовими» [1, с. 71].

Особистісний розвиток, як багатогранний процес, у своєму змісті передбачає кількісні та якісні зміни у свідомості (погляди, переконання, ідеали, щіннісні орієнтації, життева позиція тощо); психологічних процесах як пізнавальних, так і емоційних, що відображається зокрема в організації мислення, творчій діяльності, емоційній стійкості, емоційному інтелекті та емоційній зрілості; сумарності знань, умінь, навичок та компетентностей; розвитку здібностей тощо. Шлях осо- 
бистісного розвитку спрямований на досягнення особистісної зрілості та самодостатності. Це відбувається через здобуття суб'єктом нового досвіду та трансформацію поведінки у відповідності до цих змін. Забезпечуючими механізмами таких змін є індивідуалізація та інтеграція. Завдяки індивідуалізації студент в умовах дистанційного навчання може проявити себе, виявити свою індивідуальність, як в офіційній навчальній спільноті, так і участю в інших групах, інтегруючись відповідно до критерї̈ суміжності та продуктивності. Студенти в образі «аватарки» мають більші резерв сміливості, комунікативності, конструктивної інтегруючої поведінки, ніж в межах середовища аудиторного навчання ЗВО. Супровідним до цього є профресійне становлення студента, яке спрямоване на профресійне самовизначення і проходить відповідно до періоду навчання декілька етапів: професійна адаптація в межах навчальної діяльності, профресійне спрямування (формування профресійних цінностей, поглядів, намірів), професійна готовність майбутнього фрахівця. За умов дистанційного навчання така організація профресіоналізації відповідає реальності у відповідності до мережі віртуальної інфрраструктури, яка інформаційно уможливлює такий процес.

Отже, дистанщійне навчання $є$ складовою освітнього середовища, що впливає на особистісний та профресійний розвиток студента, пропонуючи спектр можливостей задля задоволення освітніх потреб в межах освітніх програм та активним залученням у студентське життя через участь у різних соціально-громадських проектах, які здійснюються за допомогою віртуальних можливостей освітнього простору.

Педагогічна улова щодо трансоборлаиї організаиійно-злістового та предлетно-ббункиіонального колпоненту освітнього середовища ЗВО до вилог иифровізаиї дистаниійного навчання. Сучасні цифррові технології є органічним функціональним компонентом який безмежно розширюе можливості дистанційного (електронного) навчання.

Організаційно-змістовий та предметно-фрункціональний компоненти включають: організаційно-розпорядче забезпечення; наукове забезпечення; навчально-методичне забезпечення; матеріально-індраструктурне забезпечення.

Вимогою цифрового освітнього середовища ЗВО є змінні форми електронного представлення нормативно-розпорядчих документів, організаційного та навчально-методичного забезпечення освітніх програм та освітніх проектів, що визначають діяльність навчального закладу; оцифровки бібліотечного ресурсу закладу; адаптації форм і методів навчання у відповідності до специфріки освітніх платформ; інформативного офрормлення сайтів, сторінок в соціальних мережах, які забезпечують функціонування освітньої установи в умовах віртуальної реальності. Важливо, щоб програмні можливості забезпечували інтерактивну взаємодію (письмова комунікація, відеозв'язок) у будь-якому контенті освітнього середовища - організаційно-розпорядчому, науковому, навчально-методичному, культурно-дозвільному. Створюючи можливості для відгуків, формування чатів та форумів, навчальних та на- укових спільнот; онлайн-конференцій, дебатів, дискусій, вебінарів, майстер-класів тощо, освітне середовище ЗВО перетворюється у формотворчу «живу» субстанцію, яка здатна забезпечити якісний освітній результат.

Беззаперечно, вагомим чинником оптимального фрункціонування дистанційного (електронного) навчання є кадровий потенціал, тьюторська ффункція якого е забезпечуючою.

Важливими вимогами до створення навчально-методичного забезпечення у методиці дистанційного навчання $є$ : змістовність, логічність, доречність, зрозумілість, структурованість, інтерактивність, оцінка затратності часу i сил у виконанні завдань для самостійної роботи студента, передбаченість термінів виконання, лаконічність відеоконтенту, прозорість, відкритість, оптимальність. На якість дистанційного навчання також впливають санітарно-гігієнічні умови, які забезпечуе якість тексту, зв'язку, тривалістю роботи за комп'ютером тощо.

Дистанщійне навчання відрізняеться від традищійного насамперед місцем та обсягом часу. Студент переважно вчиться вдома, за комп'ютером, а підготовка до навчальних занять вимагає більшого обсягу часу, оскільки здобувач знань переважно самостійно опрацьовує велику кількість джерел.

Ці особливості є причинами деяких небезпечних фракторів, що впливають на психічний та фpiзичний стан студента:

- режим роботи. Під час дистанційного навчання студенту необхідно працювати в посиленому режимі, оскільки дистанційне навчання вимагає грунтовнішої підготовки. Звісно, такий режим вимагає від студента вміння організовувати та розподіляти власний час;

- напруга опорно-рухового апарату. Внаслідок довготривалого сидіння відбувається перевтома усього організму. Цей небезпечний фрактор також залежить від самого студента, оскільки фрізичні навантаження покрашують загальний фізичний стан після довготривалого сидіння;

- великий обсяг інфрормації. Студент має вміти обробляти інформацію, обирати серед навчальних матеріалів те, що є важливим та необхідним для засвоєння матеріалу;

- інтелектуальне та емоційне навантаження. Через відсутність живого спілкування між студентами та викладачами можуть виникати конфрлікти, вирішення яких залежить від вміння налагоджувати комунікацію.

Четвертою педагогічною уловою $є$ готовність студентів до навчання в освітньолу середовищі університету із впровадженням дистаниійної технологї.

Готовність студентів до навчання організованого у відповідності до дистанційної технології, передбачає особистісне налаштування до відповідної діяльності у відповідних обставинах.

У структурі готовності студентів до пізнавальної діяльності в умовах дистанщійного навчання виділяемо такі компоненти:

- організаційно-лотиваційний колпонент. Його основою $є$ внутрішнє ставлення та мотивація студентів до навчання в дистанційному форматі;

- злістово-бункиіональний колпонент складається із різноманітних форм, методів та засобів навчання в умовах дистанційного навчання; 
- інфбраструктурно-ресурсний колпонент це освітні платформи дистанщійного (електронного) навчання.

Критеріями ефективності дистанційного навчання в умовах освітнього середовища університету є:

- організаційно-мотиваційна готовність, яка визначається інтересом до електронного ресурсу, бажанням вивчати можливості інших освітніх платформ, активна участь в освітніх спільнотах, форумах тощо; використання в навчальній діяльності додаткового відеоматеріалу, досвіду із вебінарів, майстер-класів тощо;

- змістово-фрункціональна готовність навчатися у відповідності до методів, прийомів та засобів, що використовуються в організації дистанційного навчання в межах онлайн занять та самостійної навчально-пізнавальної діяльності студента;

- інфраструктурно-ресурсна готовність володінням цифрової грамотності визначатися на різноманітних освітніх платформах та програмах.

Показники едрективності навчання студентів в умовах дистанційного навчання:

- організаційно-мотиваційні - визначаються стійкою мотивацією та інтересом студентів до участі в різноманітних освітніх спільнотах, а також виконання самостійної роботи в межах комплексного дослідження інформаційного інтернет-ресурсу відповідно до навчальних та наукових запитів;

- змістово-фрункщіональний показник характеризуеться підбором методів та засобів дистанщійного навчання відповідно до змісту та мети онлайн-заняття та самостійної роботи студента;

- інфрраструктурно-ресурсний показник визначається комплексом можливостей освітніх платформ та програм, що відповідають освітнім завданням, та вмінням студента використовувати їх.

Визначення структурних компонентів, критеріїв та показників готовності студентів до дистанційного навчання в умовах освітнього середовища університету дозволяе сорормувати рівні готовності, які забезпечують наявність чи відсутність показників у кількісному та якісному вимірі.

Рівні готовності студентів до дистанційного навчання:
- низький - студент не готовий до навчання, йому важко адаптуватись та виконувати завдання відповідно до вимог, невміння користуватись технічними і програмними можливостями освітніх платформ та програм, відсутність бажання до пошуку додаткової інформащії, незалученість до освітніх спільнот, інформаційна необізнаність із вимогами до навчальних курсів, організаціі навчання у даних умовах тощо;

- середній - студент частково готовий до навчання, вміє користуватись технічними засобами навчання, залучений до навчання лише в межах академічної групи, не виявляє бажання до самостійної навчально-пізнавальної діяльності, утрудена інтерактивна педагогічна взаємодія, формальне дотримання вимог;

- високий (творчий) - студент вмотивований, виявляє стійке позитивне ставлення до дистанційного навчання, готовий до комунікативної взаємодії, використовує додаткові навчальні ресурси, активний учасник освітніх кооперацій, залучений до низки освітніх проектів, здійснюе запит не тільки на додаткову самостійну навчальну, а й наукову діяльність, здатен до виготовлення та презентації свого освітнього відеоконтенту тощо.

Отже, педагогічні умови організації дистанційного навчання $е$ низкою компонентів, розуміння яких дає змогу сформувати комплексне уявлення про ефективну організацію дистанційного навчання в умовах університету.

Висновки 3 даного дослідження i перспективи. Впровадження дистанційного навчання $є$ складним процесом, що вимагає дотримання всіх принципів та закономірностей навчання, знання психолого-педагогічних засад та особливостей провадження дистанційного навчання в освітне середовище університету. Проектування освітнього середовища університету, у відповідності до вимог сучасності, безпосередньо пов'язане із технологією дистанщійного навчання, оскільки освітня траєкторія кожного студента, як замовника освітньої послуги, передбачає не тільки освітні результати, а й особистісне та профресійне зростання, що безумовно пов'язане із психолого-педагогічними та організащійно-дидактичними умовами навчання.

\section{Список літератури:}

1. Братко М.В. Структура освітнього середовища вищого навчального закладу. Наукові записки. Серія : Педагогічні науки. 2015. № 135. С. 67-72.

2. Демкин В.П. Организационно-методическая работа при дистанционном обучении. Открытое и дистаниионное образование. Томск, 2002. № 2(6). С. 15-23.

3. Іщенко В.С. Педагогічні умови формування аналітичної компетентності майбутніх фрахівців із документознавства та інформаційної діяльності. Народна освіта. 2017. № 3. С. 27-33.

4. Наказ Міністерства освіти і науки України "Про затвердження Положення про дистанційне навчання" від 25.04.2013 № 466. URL: https://zakon.rada.gov.ua/laws/show/z0703-13\#Text

5. Науменко С.О. Психолого-педагогічні засади та практичний досвід створення дистанційного курсу. Педагогіка, психологія та медико-біологічні проблели фбізичного виховання і спорту. 2010. № 7. С. 66-69.

6. Огієнко O.I. Дистанційна педагогічна освіта: зарубіжний та вітчизняний досвід. Методичні рекомендації. URL: http://ipood.com.ua/data/NDR/Information_technology/2012_Ogienko_recomend.pdf

7. Савченко О.Я. Дидактика початкової школи : Підручник для студентів педагогічних фракультетів. Київ : Генеза, 2002. 368 с.

8. Смульсон М.Л. Дистанційне навчання: психологічні засади : монографрія. Кіровоград : Імекс-ЛТД, 2012.240 с.

9. Сосницька Н., Глікман С. Студентоцентрований підхід до професійної освіти в умовах сталого розвитку суспільства. Науковий вісник Льотної акаделії. Серія : Педагогічні науки. 2017. № 1. С. 377-381.

10. Стеценко Н. Проблеми організації дистанціного навчання у закладах вищої освіти в умовах карантину. URL: https://conf.ztu.edu.ua/wp-content/uploads/2021/05/152-2.pdf

11. Ткачук Л. В. Психологічні особливості дистанційного навчання як перспективної освітньої технології. URL: http://www.zippo.net.ua/data/files/KafPsihol/NavchRobota/lvtkachuk_02.pdf 
12. Фальштинська Ю.В. Методологічні та психологічні проблеми використання інформаційно-комунікаційних технологій у дистанційному навчанні. Вісник Житолирського державного університету ілені Івана Франка. 2016. № 3(85). С. 143-148.

\section{References:}

1. Bratko M.V. (2015) Struktura osvitnoho seredovyshcha vyshchoho navchalnoho zakladu [The structure of the educational environment of higher education]. Proceedings. Series: Pedagogical sciences, vol. 135, pp. 67-72.

2. Demkin V.P. (2002) Orhanyzatsyonno-metodycheskaia rabota pry dystantsyonnom obuchenyy. Otkrytoe y dystantsyonnoe obrazovanye [Organizational and methodical work in distance learning]. Open and distance education, vol. 2 , no. 6 , pp. $15-23$.

3. Ishchenko V.S. (2017) Pedahohichni umovy formuvannia analitychnoi kompetentnosti maibutnikh fakhivtsiv iz dokumentoznavstva ta informatsiinoi diialnosti [Pedagogical conditions for the formation of analytical competence of future specialists in document science and information activities]. Public education, vol. 3, pp. 27-33.

4. Nakaz Ministerstva osvity i nauky Ukrainy «Pro zatverdzhennia Polozhennia pro dystantsiine navchannia» vid 25.04.2013 № 466 [Order of the Ministry of Education and Science of Ukraine «On approval of the Regulations on distance learning» dated 25.04.2013 № 466]. Available at: https://zakon.rada.gov.ua/laws/show/z0703-13\#Text (accessed 1 November 2021).

5. Naumenko S.O. (2010) Psykholoho-pedahohichni zasady ta praktychnyi dosvid stvorennia dystantsiinoho kursu [Psychological and pedagogical principles and practical experience of creating a distance course]. Pedagogy, psychology and medical and biological problems of physical education and sports, vol. 7, pp. 66-69.

6. Ogienko O.I. (2012) Dystantsiina pedahohichna osvita: zarubizhnyi ta vitchyznianyi dosvid. Metodychni rekomendatsii [Distance pedagogical education: foreign and domestic experience. Guidelines]. Kyiv: National Academy of Pedagogical Sciences of Ukraine. Institute of Pedagogical Education and Adult Education. Available at: http://ipood.com.ua/data/NDR/Information_technology/2012_Ogienko_recomend.pdf (accessed 14 November 2021). (in Ukrainian)

7. Savchenko O. Ya. (2002) Dydaktyka pochatkovoi shkoly: Pidruchnyk dlia studentiv pedahohichnykh fakultetiv [Didactics of primary school: A textbook for students of pedagogical faculties]. Kyiv: Geneza. (in Ukrainian)

8. Smulson M.L. (2012) Dystantsiine navchannia: psykholohichni zasady: monohrafiia [Distance learning: psychological principles: monograph]. Kirovograd: Imex-LTD. (in Ukrainian)

9. Sosnytska N., Glikman S. (2017) Studentotsentrovanyi pidkhid do profesiinoi osvity v umovakh staloho rozvytku suspilstva [Student-centered approach to vocational education in terms of sustainable development of society]. Scientific Bulletin of the Flight Academy. Series: Pedagogical sciences, vol. 1, pp. 377-381.

10. Stetsenko N. Problemy orhanizatsii dystantsinoho navchannia u zakladakh vyshchoi osvity $\mathrm{v}$ umovakh karantynu [Problems of distance learning in higher education institutions in quarantine]. Available at: https://conf.ztu.edu.ua/wp-content/uploads/2021/05/152-2.pdf (accessed 1 November 2021).

11. Tkachuk L.V. Psykholohichni osoblyvosti dystantsiinoho navchannia yak perspektyvnoi osvitnoi tekhnolohii [Psychological features of distance learning as a promising educational technology]. Available at: http://www.zippo.net.ua/data/files/KafPsihol/NavchRobota/lvtkachuk_02.pdf (accessed 3 November 2021).

12. Falshtynska Yu.V. (2016) Metodolohichni ta psykholohichni problemy vykorystannia informatsiinokomunikatsiinykh tekhnolohii $\mathrm{u}$ dystantsiinomu navchann [Methodological and $\mathrm{p}$ sychological problems of using information and communication technologies in distance learning] Bulletin of Zhytomyr State University named after Ivan Franko, vol. 3, no. 85, pp. 143-148. 